\title{
MENINGKATKAN HASIL BELAJAR LOMPAT JAUH MELALUI PENERAPAN METODE BERMAIN PADA SISWA KELAS V SD NEGERI 1 BARUGA KOTA KENDARI
}

\author{
oleh: \\ ASMUDIN \\ Dosen Jurusan Pendidikan Jasmani, Kesehatan dan Rekreasi, \\ Fakultas Keguruan dan Ilmu Pendidikan Universitas Halu Oleo \\ Email: -
}

\begin{abstract}
ABSTRAK
Tujuan Penelitian ini adalah untuk mengetahui keefektifan penerapan metode bermain dalam meningkatkan hasil belajar lompat jauh siswa kelas V SDN 1 Baruga. Penelitian ini termasuk penelitian tindakan kelas. Karakteristik yang khas dari penelitian tindakan kelas yakni adanya tindakan tertentu (action) untuk memperbaiki proses belajar mengajar guna mencapai tujuan pengajaran serta peningkatan mutu pendidikan. Penelitian tindakan kelas (PTK) ini dilaksanakan pada semester genap tahun ajaran 2017/2018 pada siswa kelas V SDN 1 Baruga. Subjek penelitian tindakan kelas ini adalah siswa kelas V SDN 1 Baruga yang berjumlah 24 orang yang terdiri dari 11 siswa putri dan 13 siswa putra. Prosedur penelitian tindakan kelas ini dilakukan dua siklus, dengan tiap siklus dilaksanakan satu kali pertemuan sesuai dengan perubahan yang ingin dicapai pada faktor-faktor yang ingin diselidiki. Dari hasil observasi awal yakni berupa wawancara langsung dengan guru bidang studi penjaskes SDN 1 Baruga, untuk menjawab masalah dalam pembelajaran lompat jauh ditetapkan bahwa tindakan yang akan digunakan untuk meningkatan hasil belajar lompat jauh siswa adalah adanya penggunaan metode pembelajaran bermain dalam proses pembelajaran lompat jauh. Sebagai indikator keberhasilan dalam penelitian tindakan kelas ini adalah apabila siswa yang memperoleh 70 sudah mencapai angka $75 \%$ maka penelitian ini dikatakan tuntas. Berdasarkan hasil analisis data dan pembahasan yang telah di kemukakan sebelumnya, untuk tingkat ketuntasan belajar siswa pada siklus I jumlah siswa yang tuntas hanya $70,83 \%$, Selanjutnya pada Siklus II jumlah siswa yang tuntas meningkat menjadi $91,66 \%$ atau terjadi peningkatan sebesar 20,83\%. Dengan demikian maka hasil penelitian ini dapat disimpulkan bahwa hasil belajar lompat jauh siswa kelas V SDN 1 Baruga dapat meningkat melalui penerapan metode bermain.
\end{abstract}

\section{Kata Kunci: Hasil Belajar, Metode Bermain, Lompat Jauh}

\section{PENDAHULUAN}

Berbagai aktivitas siswa dengan segala keriangannya dapat kita jumpai. Hampir seluruh ruang kosong yang dimiliki sekolah diisi dengan berbagai aktivitas permainan perorangan maupun kelompok, baik tanpa menggunakan alat maupun dengan menggunakan alat yang sederhana dan bahkan mereka siapkan sendiri. Hal ini dapat dijadikan inspirasi bagi para guru pendidikan jasmani untuk melaksanakan kegiatan pembelajaran agar lebih terarah dan dapat disesuaikan dengan program kurikulum.

Dinamika dari suatu permainan yang merangsang anak untuk bergerak 
dan terus bergerak, secara perlahan akan merangsang pertumbuhan serta perkembangan fisik si anak. Apalagi kalau situasi permainan tersebut menyenangkan bagi mereka, dimana rasa senang, puas serta berbagai keberhasilan akan mereka rasakan dari kegiatan yang sedang mereka lakukan tersebut akan menumbuh kembangkan aspek-aspek psikologis mereka secara positif.

Kenyataan selama ini pilihan utama para guru pendidikan jasmani dalam melakukan pembelajaran cenderung terfokus pada aktivitas atletik yang bercirikan pembelajaran teknis sehingga seringkali terkesan membosankan dan pada akhirnya kurang diminati siswa serta mungkin juga akhirnya guru sendiri kurang tertarik pada aktivitas pembelajaran atletik pada khususnya. Dalam dunia pendidikan (sekolah), materi lompat jauh merupakan salah satu cabang olahraga nomor Atletik yang diajarkan di sekolah yang terangkum dalam kurikulum pendidikan jasmani. Melakukan lompat jauh dengan baik dan benar bagi siswa sekolah bukan merupakan hal yang mudah.

Bagi siswa pemula sering kali dalam melakukan teknik lompat jauh tidak tepat dan sering melakukan kesalahan, Kondisi yang demikian tentunya akan menyebabkan rendahnya nilai hasil belajar yang dicapai oleh siswa, Ada beberapa faktor penyebab sehingga terjadi hal yang demikian diantaranya adalah kurang kreatifnya Guru pendidikan jasmani dalam berkreasi maupun berinovasi mengembangkan media pembelajaran yang sifatnya sederhana. Apalagi pada umumnya di Sekolah Dasar sarana khususnya lompat jauh sangat terbatas jumlahnya yang tidak sesuai dengan jumlah siswa yang akan mengunakannya dan dengan kurangnya media inilah juga yang menyulitkan Guru mentransfer ilmu kepada siswanya sehingga proses pembelajaran menjadi tidak maksimal.

Hal ini pulalah yang terjadi di salah satu sekolah dasar di Kecamatan Baruga Kabupaten Konawe Selatan tepatnya di SDN 1 Baruga dimana berdasarkan hasil observasi penulis menemukan fakta bahwa tingkat ketuntasan belajar di kelas $\mathrm{V}$ yang sangat rendah yang berkisar pada angka $60 \%$, dimana para siswa khususnya yang putri kurang antusias terhadap materi lompat jauh dimana mereka merasa kurang percaya diri dan tidak dapat melaksanakan tugas praktek yang diberikan oleh guru diakibatkan media yang digunakan masih dalam kondisi standar.

\begin{tabular}{lcr}
\multicolumn{2}{c}{ Berdasarkan fakta yang } \\
dikemukakan tersebut dan untuk \\
menyesuaikan & dengan & tingkat
\end{tabular} kemampuan fisik siswa maka dalam penelitian ini penulis berusaha mengembangkan media pembelajaran yang dapat diaplikasikan siswa dengan cara memodifikasi pembelajaran lompat jauh agar siswa dapat melaksanakan pembelajaran materi lompat jauh dengan bersemangat, aktif, dan menyenangkan, Kemudian Siswa memperoleh kepuasan dalam mengikuti pelajaran. Selanjutnya meningkatkan kemungkinan keberhasilan siswa dalam berpartisipasi, Siswa dapat melakukan pola gerak dasar dengan benar, serta juga akan berdampak pada meningkatnya kondisi kesegaran jasmani siswa. Sehubungan dengan hal tersebut untuk dapat merealisasikan proses pelaksanaan metode pembelajaran bermain dengan media yang dimodifikasi dalam hal ini 
penggunaan media bantu karet gelang, dan dus bekas maka peneliti mengadakan suatu penelitian yang terangkum dalam judul "Meningkatkan hasil belajar lompat jauh melalui penerapan metode bermain pada siswa kelas V SDN 1 Baruga".

\section{Hasil Belajar}

Hasil belajar adalah kemampuan yang diperoleh anak dari suatu interaksi dalam proses pembelajaran, (Wina Sanjaya, 2009). Selanjutnya Ade Mardiani, (2008), mengatakan bahwa hasil belajar merupakan hasil akhir pengambilan keputusan mengenai tinggi rendahnya nilai yang diperoleh siswa selama mengikuti proses pembelajaran. Hasil belajar dikatakan tinggi bila tingkat kemampuan siswa bertambah. Berkaitan dengan hasil belajar yang diperoleh sebagai hasil belajar terdapat tiga tipe hasil belajar menurut Sujana (2004), yaitu:

1. Tipe hasil belajar kognitif meliputi pengetahuan, pemahaman, penerapan, analisis sintesis, dan evaluasi.

2. Tipe hasil belajar bidang afektif meliputi penerimaan, jawaban, penilaian, organisir, dan karakteristik nilai.

3. Tipe hasil belajar bidang psikomotor meliputi tingkatan keterampilan.

Berdasarkan pernyataan tersebut dapat dipahami bahwa yang menjadi ukuran hasil belajar siswa adalah ranah kognitif, afektif, ranah psikomotor. Pendapat lain dikemukakan oleh Hamalik, (2011), mengenai hasil belajar beliau menjelaskan bahwa untuk mengetahui tingkat kemampuan/kemajuan siswa dalam melakukan kegiatan/aktivitas jasmani yang ditinjau dari segi pengetahuan, sikap maupun keterampilan dan kemampuan dalam menyerap informasi yang diberikan guru selama proses pembelajaran tentunya diperlukan suatu evaluasi atau penilaian yang dengan penilaian ini seorang guru akan mengetahui sejauh mana keberhasilan suatu metode mengajar yang dipergunakan.

Berdasarkan uraian di atas, jelas bahwa suatu proses belajar mengajar pada akhirnya akan menghasilkan kemampuan siswa yang mencakup pengetahuan sikap dan keterampilan, dalam artian bahwa perubahan kemampuan merupakan indikator untuk mengetahui hasil belajar siswa. Dengan demikian dapat dipahami bahwa hasil belajar merupakan hasil yang diperoleh siswa setelah ia menerima suatu pengetahuan yang berupa angka/nilai. Jadi aktivitas siwa mempunyai peranan yang sangat penting dalam proses belajar mengajar, tanpa adanya aktivitas siswa maka proses belajar mengajar tidak akan berjalan dengan baik, akibatnya hasil belajar yang dicapai siswa rendah.

\section{Hakekat Lompat Jauh}

Lompat jauh adalah salah satu nomor yang terdapat pada nomor lompat yang meliputi cara melakukan awalan, tumpuan, melayang di udara dan cara melakukan pendaratan (Tamsir Riyadi: 1985). Lompat jauh adalah lompatan horizontal untuk mencapai jarak (Ballesteros, 1979). Lompat jauh adalah lompat untuk mencapai jarak yang sejauh- jauhnya yang mempunyai unsur-unsur pokok meliputi awalan, tolakan, sikap badan ketika berada di udara, sikap badan pada waktu jatuh atau mendarat (Engkos, 1985). Dalam lompat jauh ada beberapa macam teknik atau gaya dalam melakukan lompatan yaitu the sail, the hang, dan the hitech 
kick (Ballesteros, 1979). Gaya dalam lompat jauh yaitu gaya jongkok, gaya tegak, gaya jalan (Tamsir Riyadi, 1985) Gaya lompat jauh yang lain terdiri dari 4 unsur atau teknik yaitu :

1. Teknik awalan. Awalan atau ancangancang adalah gerakan permulaan dalam bentuk lari untuk mendapatkan kecepatan horizontal pada waktu akan melakukan tolakan. Kecepatan lari awalan dan besarnya sudut tolakan merupakan komponen unsur-unsur yang menentukan pencapaian jarak lompatan (Ballesteros, 1979).

2. Teknik tumpuan atau tolakan. Maksud dari tolakan atau take off adalah merubah gerakan lari menjadi suatu lompatan. Dengan melakukan lompat tegak lurus sambil mempertahankan kecepatan horisontal (Ballesteros, 1979). Yang perlu diperhatikan dalam melakukan tolakan yakni:

(a) Tolakan dilakukan dengan kaki yang terkuat (Tamsir Riyadi, 1985).

(b) Menghindari hilangnya kecepatan horizontal sudut proyeksi tidak boleh terlalu besar (Derek Boosey, 1980). Mengenai sudut tolakan Derek Boosey (1980:122) berpendapat bahwa berdasarkan pengamatan terhadap atlet-atlet yang baik menunjukkan sudut tolakan yang bermacam-macam sebagian besar jatuh antara $15^{\circ}$ dan $25^{\circ}$, .

3. Sikap badan di udara lompat jauh yaitu, waktu lepas dari papan tolak, kedua tungkai di udara dalam keadaan jongkok, kedua lutut ditekuk, kedua tangan ke depan. Pada waktu akan mendarat kedua tungkai dijulurkan ke depan kemudian mendarat dengan kedua kaki.

4. Teknik mendarat. Mendarat merupakan gerakan terakhir dari rangkaian gerakan lompat jauh. Mendarat bertujuan mendapatkan suatu posisi dengan kedua kaki menyentuh pasir sejauh mungkin di depan pusat dari gaya berat tubuh pelompat (Tamsir Riyadi, 1985). Pendaratan sebaiknya dilakukan dengan kedua belah kaki dan pada bagian tumit terlebih dahulu. Sebelum tumit menyentuh pasir, kedua kaki diluruskan ke depan. Jarak antara kaki jangan terlalu berjauhan. Setelah tumit berpijak pada pasir. Kedua lutut segera ditekuk dan badan condong ke depan, kedua tangan dijulurkan ke depan (Tamsir Riyadi, 1985).

Ada 2 cara mendarat dalam

lompat jauh yaitu,

a) Kedua tungkai di julurkan ke depan seperti menyekop dan kemudian setelah menyentuh lutut ditekuk di depan badan.

b) Pada gerakan atlet meluruskan atau mengunci salah satu lutut dan melenturkan lutut yang lain, maka pada saat menyentuh pendaratan terjadi lutut yang terkunci dipakai sebagai tumpuan dan berayun disisi lutut yang rifleks (lentur), sementara badan menjatuhkan pada sisi menyentuh pendaratan (Boosey, 1980).

Berdasarkan uraian tinjauan teknik lompat jauh dapat disimpulkan sebagai berikut: 
a) Pada waktu melakukan awalan dengan lari dari pelan semakin dipercepat, kecepatan dipertahankan sampai menjelang bertolak.

b) Pada saat melakukan tolakan, kaki yang digunakan menolak (take off) harus tepat pada papan tumpu.

c) Lompat jauh, gaya jongkok pada saat ketinggian maksimal sikap badan dan Kaki jongkok, setelah bergerak turun kedua kaki diluruskan ke depan.

d) Saat gerakan mendarat dilakukan dengan kedua kaki secara bersamaan, sejajar dan lutut segera ditekuk, kedua tangan ke depan badan condong ke depan.

\section{Hakekat Metode Bermain}

Dalam kegiatan belajar mengajar metode akan mempengaruhi proses pencapaian tujuan. Seperti yang dikemukakan oleh Iskandar (2011), yang dimaksud metode dalam kegiatan belajar mengajar adalah seperangkat upaya yang dilaksankan dan disusun dengan tujuan menciptakan suasana belajar mengajar yang menguntungkan hal ini mengandung arti bahwa dalam suatu kegiatan belajar mengajar guru telah mempersiapkan segala sesuatunya dengan sedemikian rupa sehingga nantinya dapat tercipta situasi belajar mengajar yang menguntungkan.

Metode pembelajaran memegang peranan sangat penting dalam penyusunan strategi dan pelaksanaan kegiatan pembelajaran. Metode dapat diartikan cara yang berkaitan dengan pengorganisasian kegiatan belajar bagi siswa seperti kegiatan individual, kegiatan belajar kelompok, atau kegiatan belajar massal. Metode pada dasarnya berfungsi sebagai alat untuk mencapai tujuan dan menentukan baik tidaknya suatu pembelajaran, diperlukan patokan (kriteria). Salah satu kriteria utama yang menentukan dalam penggunaan metode adalah tujuan yang akan dicapai.

Dalam pelaksanaan pembelajaran, selain kriteria tujuan, diperlukan kriteria lain yaitu: peserta didik, situasi, kemampuan guru, dan sebagainya. Oleh karena itu penggunaan suatu metode banyak tergantung pada kemampuan guru yang bersangkutan dalam melaksanakan kegiatan belajar mengajar. Karena dalam setiap proses pembelajaran terjadi peristiwa belajar mengajar. Kegiatan pembelajaran tidak dapat dipisahkan dari kegiatan belajar mengajar karena pembelajaran pada hakekatnya adalah aktivitas belajar antara guru dan siswa. Menurut Iskandar (2011), yang dimaksud dengan pembelajaran adalah pengalaman belajar yang dialami oleh siswa dalam proses menguasai tujuan pembelajaran khusus.

Pelaksanaan pembelajaran pendidikan jasmani khususnya materi lompat jauh, maka pembelajaran pendidikan jasmani dengan materi lompat jauh adalah kegiatan belajar mengajar yang dialami oleh siswa dalam proses menguasai tujuan pembelajaran khusus mata pelajaran pendidikan jasmani yang membahas mengenai materi lompat jauh. Proses pembelajaran terdapat unsur tujuan pembelajaran tujuan instruksional, proses pembelajaran dan hasil pembelajaran, Untuk mencapai tujuan tersebut tentunya dibutuhkan metode atau cara yang pas agar proses pembelajaran menjadi lebih berkualitas dan yang akan berefek pada meningkatkanya kualitas hasil belajar siswa. Hal ini sesuai dengan pendapat yang dikemukakan oleh Yudha $\mathrm{M}$. Saputra (2010), bahwa metode 
pembelajaran merupakan cara-cara spesifik yang dapat dilakukan oleh individu untuk membuat siswa mencapai tujuan pembelajaran atau standar kompetensi yang telah ditentukan. Untuk membelajarkan pendidikan jasmani yang tepat, maka perlu diterapkan metode pembelajaran yang baik dan tepat.

Yoyo Bahagia (2001), berpendapat bahwa, "Cara-cara atau metode yang sering digunakan dalam pengajaran gerak olahraga salah satunya adalah dengan bermain. Metode bermain merupakan suatu cara yang diterapkan seorang guru dalam kegiatan pembelajaran yang dikemas dalam bentuk bermain atau permainan. Kegiatan bermain adalah suatu aktifitas yang disukai oleh anak-anak yang dapat mendatangkan kegembiraan.

Supandi (1992), bahwa bermain sebenarnya merupakan dorongan dari dalam anak, atau naluri. Ciri lain yang sangat mendasar yakni kegiatan itu dilakukan secara sukarela tanpa paksaan dalam waktu luang. Selanjutnya Yudha (2010), menjelaskan seorang anak dapat mengenal ruang, waktu, jarak hanya melalui ekspresi gerak, dari sifat anak yang selalu bergerak dan senang bermain ini sangat mendukung aktivitas pendidikan jasmani di Sekolah. Sehingga pembelajaran jasmani di Sekolah harus mampu mengembangkan kemampuan anak secara multilateral yang dilakukan melalui bermain.

Pendapat para ahli tersebut selaras dengan kurikulum penjas yang menyediakan begitu banyak alternative gerak-gerak yang mengandung sifat permainan untuk pengayaan gerak. Berdasarkan karakteristik pada usia anak-anak tersebut, maka dalam membelajarkan suatu keterampilan olahraga harus disesuaikan dengan karakteristik perkembangannya. Pendekatan bermain merupakan suatu metode pembelajaran yang dikonsep dalam bentuk permainan. Dengan bermain hasrat gerak anak terpenuhi, namun didalamnya terkandung unsur pembelajaran. Pendekatan permainan bertujuan untuk mengajarkan permainan agar anak memahami manfaat teknik permainan tertentu dengan cara mengenalkan situasi permainan terlebih dahulu kepada anak.

$\begin{array}{ccc}\text { Yoyo } & \begin{array}{c}\text { Bahagia } \\ \text { menyatakan }\end{array} & \text { (2001), } \\ \text { dalam }\end{array}$ bentuk permainan bertujuan untuk meningkatkan kesadaran siswa tentang konsep bermain melalui penerapan teknik yang tepat sesuai dengan masalah atau situai dalam permainan yang sesungguhnya. Selanjutnya Supandi (1992), menjelaskan bahwa dengan bermain anak akan mengekspresikan kegembiraannya dan berusaha menampilkan kemampuannya. Namun disisi lain seorang guru harus menanamkan sikap sportivitas, karena dalam bermain ada yang menang ada yang kalah maka guru harus pula mengembangkan sikap seorang yang menang dan sikap seorang yang kalah secara fair kepada siswa, karena sikap itu seperti tidak terbentuk dengan sendirinya melalui permainan, maka usaha pengembangan sikap ini harus dilakukan secara terencana dan disengaja guru.

Berdasarkan pendapat tersebut menunjukan bahwa pendekatan bermain di dalamnya terkandung pembelajaran yang cukup kompleks yaitu penguasaan teknik cabang olahraga yang dipelajari, penerapan taktik yang baik dan memecahkan masalah yang terjadi di dalam 
permainan serta pembentukan sikap mental yang saling menghargai.

Kelebihan dari pembelajaran bermain adalah :

a) Menggunakan kemampuan fantasi dalam proses pembelajaran untuk membangun hubungan dengan realitas dan kehidupan nyata,

b) Memuji keindahan perbedaan potensi, karakter, bakat dan minat serta modalitas gaya belajar individu siswa,

c) Menciptakan suasana belajar yang kondusif dan bebas dari tekanan dan intimidasi dalam usaha meyakinkan minat belajar siswa,

d) Mendorong terjadinya proses pembelajaran interaktif, agar terbentuk budaya belajar yang bermakna (meaningful learning) pada siswa,

e) Memberikan tes/ujian yang bisa mendorong terjadinya umpan balik dan semangat/gairah pada siswa untuk ingin mempelajari materi lebih dalam. (Supandi, 1992).

Pendidikan jasmani dan olahraga merupakan pendidikan yang dilakukan melalui aktivitas fisik sebagai media utama untuk mencapai tujuan. Bentukbentuk aktivitas fisik yang lazim digunakan oleh anak SD, Sesuai dengan muatan yang tercantum dalam kurikulum adalah bentuk gerak-gerak olahraga, sehingga pendidikan/jasmani SD memuat cabang-cabang olahraga. Untuk mencapai tujuan tersebut, guru pendidikan jasmani dan olahraga harus dapat merancang dan melaksanakan pembelajaran pendidikan jasmani dan olahraga sesuai dengan tahap-tahap perkembangan dan karakteristik anak SD. Memodifikasi alat bantu merupakan salah satu upaya yang dapat dilakukan guru pendidikan jasmani dan olahraga SD, agar siswa dapat mengikuti pelajaran dengan senang.

Ade Mardiani, (2008), Menyatakan, modifikasi dalam mata pelajaran pendidikan jasmani dan olahraga diperlukan, dengan tujuan agar:

a) Siswa memperoleh kepuasan dalam mengikuti pelajaran,

b) Meningkatkan kemungkinan keberhasilan dalam berpartisipasi, dan

c) Siswa dapatmelakukan pola gerak secara benar.

Pendekatan modifikasi ini dimaksudkan agar materi yang ada di dalam kurikulum dapat disajikan sesuai dengan tahap-tahap perkembangan kognitif, afektif, dan psikomotor anak, sehingga pembelajaran pendidikan jasmani dan olahraga di SD dapat dilakukan secara intensif. Keterbatasan fasilitas pembelajaran pendidikan jasmani dan olahraga yang ada di SD menjadi kendala serius dalam pelaksanaannya. Modifikasi digunakan sebagai salah satu alternatif pendekatan dalam pembelajaran pendidikan jasmani dan olahraga di SD yang dilakukan dengan berbagai pertimbangan. Pendapat di atas dapat disimpulkan bahwa komponen-komponen yang dapat dimodifikasi sebagai pendekatan dalam pembelajaran pendidikan jasmani dan olahraga di SD adalah :

1. Ukuran, berat atau bentuk peralatan yang dipergunakan,

2. Ukuran lapangan permainan,

3. Lamanya waktu bermain atau lamanya permainan,

4. Peraturan permainan yang digunakan,

5. Jumlah pemain atau jumlah siswa yang dilibatkan dalam suatu permainan. 
Berdasarkan uraian tersebut dapat disimpulkan bahwa sarana dan prasarana sangat diperlukan untuk menunjang keberhasilan pendidikan jasmani dan olahraga di SD. Sarana yang memenuhi syarat untuk cabang olahraga tertentu, belum tentu memenuhi syarat untuk digunakan oleh anak SD. Berbagai gerak dasar lompat tersebut dapat dilakukan dengan menggunakan media karet gelang yang sederhana dan kardus bekas dan dapat dilakukan dimana saja, Adapun teknis pelaksanaan menggunakan media modifikasi adalah sebagai berikut:

1. Amati dan memberi waktu bagi siswa untuk melakukan metode ini

2. Memberi umpan balik kepada siswa tentang peranan siswa dalam pengambilan keputusan dalam pengambilan keputusan memilih tugas-tugas saat melakukan lompat jauh.

3. Guru menanyakan bagaimana mereka memilih tugas-tugas.

4. Fokuskan perhatian pada penggunaan umpan balik yang netral, agar siswa mengambil keputusan mengenai taraf tugas yang sesuai dengan kemampuannya.

5. Amati kesalahan-kesalahan dalam penampilan siswa dan kriteria yang menyangkut penampilan dalam tugasnya. (Katzenbogner/ Medler. 1996).

\section{METODE PENELITIAN}

\section{Jenis dan Desain Penelitian}

Penelitian ini termasuk penelitian tindakan kelas. Karakteristik yang khas dari penelitian tindakan kelas yakni adanya tindakan tertentu (action) untuk memperbaiki proses belajar mengajar guna mencapai tujuan pengajaran serta peningkatan mutu pendidikan.

\section{Subjek Penelitian}

Subjek penelitian tindakan kelas ini adalah siswa kelas V SDN 1 Baruga yang berjumlah 24 orang yang terdiri dari 11 siswa putri dan 13 siswa putra.

\section{Prosedur Penelitian}

Prosedur penelitian tindakan kelas ini dilakukan dua siklus, dengan tiap siklus dilaksanakan satu kali pertemuan sesuai dengan perubahan yang ingin dicapai pada faktor-faktor yang ingin diselidiki. Dari hasil obeservasi awal yakni berupa wawancara langsung dengan guru bidang studi penjaskes SDN 1 Baruga, untuk menjawab masalah dalam pembelajaran lompat jauh ditetapkan bahwa tindakan yang akan digunakan untuk meningkatan hasil belajar lompat jauh siswa adalah adanya penggunaan metode pembelajaran bermain dalam proses pembelajaran lompat jauh.

Prosedur pelaksanaan penelitian tindakan kelas terdiri dari :

(1) Perencanaan,

(2) Pelaksanaan tindakan,

(3) Observasi/ pengamatan,

(4) Refleksi.

Secara rinci prosedur penelitian tindakan kelas tersebut dijabarkan sebagai berikut:

\section{Perencanaan}

Kegiatan yang akan dilakukan pada tahap ini setelah ditetapkan untuk menerapkan pembelajaran lompat jauh dengan menggunakan metode pembelajaran bermain, maka kegiatan selanjutnya adalah menyiapkan beberapa hal yang perlu dilakukan sebagai berikut: 
1. Membuat skenario pembelajaran yang tercantum dalam RPP untuk siklus 1 yang dilaksanakan dalam satu kali pertemuan.(terlampir),

2. Membuat lembar observasi untuk guru dan siswa,

3. Membuat instrument penelitian yang meliputi alat evaluasi berupa tes dan panduan penskoran untuk melihat apakah ada peningkatan hasil belajar lompat jauh dengan menggunakan metode pembelajaran bermain.

\section{Pelaksanaan Tindakan}

Kegiatan yang akan dilaksanakan pada tahap ini melaksanakan pembelajaran lompat jauh dengan menggunakan metode pembelajaran bermain sebagaimana dengan rencana pembelajaran yang telah dibuat sebelumnya yang terdapat pada lampiran.

\section{Observasi dan Evaluasi}

\section{Observasi}

Kegiatan yang dilakukan pada tahap ini adalah melaksanakan proses observasi terhadap pelaksanaan tindakan dengan menggunakan lembar observasi yang telah dibuat untuk guru dan siswa. Proses ini dilakukan mulai dari awal sampai akhir pembelajaran. Adapun format observasi Guru dan siswa dapat dilihat pada lampiran 2 dan 3

\section{Evaluasi}

Kegiatan evaluasi bertujuan untuk melihat apakah ada peningkatan keterampilan lompat jauh melalui metode pembelajaran bermain menggunakan instrument tes kognitif, afektif dan psikomotor

\section{Refleksi}

Pada tahap ini, hal yang diperoleh pada tahap observasi dan evaluasi akan dikumpulkan kemudian dianalisis. Dari hasil tersebut akan terlihat apakah telah memenuhi target yang ditetapkan sesuai dengan indikator kerja. Jika belum memenuhi target, maka penelitian dilanjutkan kesiklus berikutnya. Kesalahan yang terjadi pada tindakan siklus sebelumnya akan diperbaiki pada siklus berikutnya.

\section{Data dan Teknik Pengambilan Data}

1. Sumber data: yaitu guru dan siswa Jenis data: jenis data yang akan diperoleh adalah data tentang hasil belajar siswa dan data penunjang tentang kegiatan belajar guru

2. Teknik pengambilan data

a. Data mengenai kegiatan belajar siswa lompat jauh dengan menerapkan metode bermain diambil dengan menggunakan lembar observasi/ pengamatan.

b. Data mengenai hasil belajar lompat jauh siswa diambil dengan menggunakan tes (rubrik penilaian).

\section{Indikator Kinerja}

Sebagai indikator keberhasilan dalam penelitian tindakan kelas ini adalah apabila siswa yang memperoleh 70 sudah mencapai angka $75 \%$ maka penelitian ini dikatakan tuntas. (ketuntasan dari sekolah). 


\section{HASIL DAN PEMBAHASAN}

\section{Hasil Penelitian}

\section{Deskripsi Aktifitas Siswa Selama Kegiatan Belajar Mengajar (KBM) Berlangsung}

Data aktifitas siswa selama kegiatan belajar mengajar berlangsung dapat dilihat pada lampiran 4. Untuk mengetahui aktifitas siswa kelas V SD Negeri 1 Baruga pada setiap siklus dengan pembelajaran menggunakan metode bermain. Berdasarkan tabel dapat diketahui bahwa pada siklus I jumlah indikator yang terlaksana $(\mathrm{Ya})=$ 7 indikator, sedangkan pada siklus II jumlah indikator yang terlaksana $(\mathrm{Ya})=$ 10 indikator. Jika keterlaksanaan indikator tersebut dipersentasekan, maka pada siklus I indikator yang terlaksana hanya sebesar $70 \%$ sedangkan pada siklus II indikator yang terlaksana $100 \%$. Kriteria ketuntasan aktifitas siswa dapat diketahui pada siklus II telah tercapai ketuntasan belajar yang diinginkan.

\section{Deskripsi Aktifitas Guru Selama Kegiatan Belajar Mengajar (KBM) Berlangsung}

Gambaran aktifitas guru selama dalam mengelola pembelajaran teknik dasar lompat jauh dengan menggunakan metode bermain dapat dilihat pada tabel 4.3, dimana aktifitas guru dalam mengelola pembelajaran pada siklus I tergolong kurang maksimal dan pembelajaran pada siklus II tergolong maksimal. Berdasarkan tabel dapat diketahui bahwa aktifitas guru selama KBM (kegiatan belajar mengajar) berlangsung dengan indikator yang terlaksana (Ya) pada siklus I sebanyak 8 indikator, sedangkan pada siklus II indikator yang terlaksana mencapai 11 indikator, sementara itu dapat pula diketahui bahwa persentase keterlaksanaan pada siklus I sebesar 72, $73 \%$ dan pada siklus II persentase keterlaksanaan mencapai $100 \%$. Dengan demikian diperoleh hasil persentase yang menerangkan bahwa pada siklus I tidak mencapai ketuntasan dan pada siklus II telah mencapai ketuntasan.

\section{Deskripsi Hasil Belajar}

Data hasil penelitian siswa kelas V SD Negeri 1 Baruga dapat dilihat pada tabel. Selanjutnya untuk mengetahui peningkatan hasil belajar siswa kelas $\mathrm{V}$ SD Negeri 1 Baruga setiap siklus. Berdasarkan analisis data hasil penilaian formatif menunjukan bahwa pada siklus I siswa yang tuntas hasil belajarnya sebanyak 17 orang atau $70,83 \%$ dan yang belajarnya tidak tuntas sebanyak 7 orang atau 29,16\%. Sedangkan pada siklus II siswa yang tuntas hasil belajarnya sebanyak 22 orang atau $91,66 \%$ sedangkan yang belum tuntas sejumlah dua orang atau $8,33 \%$. Jadi ketuntasan belajar siswa kelas V pada siklus II telah mencapai tingkat ketuntasan belajar yang ditetapkan oleh pihak sekolah yaitu minimal $75 \%$ siswa memperoleh nilai 70 .

\section{Pembahasan}

Berdasarkan penjelasan pertama tentang bagaimana gambaran aktifitas siswa selama kegiatan pembelajaran berlangsung, dapat dijelaskan berdasarkan hasil pengamatan pada siklus I, dimana frekuensi aktifitas siswa dapat dilihat pada tabel 4 , dari tabel tersebut, frekuensi aktifitas siswa pada siklus I menunjukan siswa kurang serius dalam mengikuti pembelajaran dengan menggunakan metode bermain dimana seluruh aspek penilaian aktifitas 
siswa tidak terlaksanakan sepenuhnya oleh siswa. Sedangkan pada siklus II seluruh aspek penilaian aktifitas siswa telah dilaksanakan sepenuhnya oleh siswa, diantaranya:

1. Siswa terampil dalam melakukan lompat jauh dalam pembelajaran.

2. Siswa bekerja sama dalam melaksanakan kegiatan lompat jauh.

3. Mempraktekan hasil materi sesuai dengan bagian-bagian atau fase gerakan lompat jauh.

Analisis deskriptif ketuntasan hasil belajar siswa pada siklus II dengan materi lompat jauh yang memperoleh nilai $>70$ atau kategori tuntas sebanyak 22 orang atau $91,66 \%$ dan siswa yang memperoleh nilai $<70$ sebanyak 2 orang atau $8,33 \%$. Ini menunjukan bahwa indikator keberhasilan siklus II sebesar $75 \%$ siswa memperoleh nilai > 70 sudah tercapai dan tidak dilanjutkan kesiklus berikutnnya.

Ketuntasan hasil belajar yang dicapai oleh siswa tidak hanya dipengaruhi oleh model pembelajaran yang diterapkan oleh guru. Akan tetapi ada faktor lain yang mempengaruhinya yaitu faktor internal dan faktor eksternal. Faktor internal yaitu segala sesuatu yang berhubungan dengan diri pribadi siswa seperti faktor fisik dan faktor psikologi/mental. Sedangkan faktor eksternal yaitu segala sesuatu diluar pribadi siswa seperti faktor sosial, faktor budaya dan lingkungan.

\section{KESIMPULAN DAN SARAN}

Berdasarkan hasil analisis data dan pembahasan yang telah di kemukakan sebelumnya, untuk tingkat ketuntasan belajar siswa pada siklus I jumlah siswa yang tuntas hanya $70,83 \%$, Selanjutnya pada Siklus II jumlah siswa yang tuntas meningkat menjadi $91,66 \%$ atau terjadi peningkatan sebesar 20,83\%. Dengan demikian maka hasil penelitian ini dapat disimpulkan sebagai berikut: bahwa hasil belajar lompat jauh siswa kelas V SDN 1 Baruga dapat meningkat melalui penerapan metode bermain.

\section{DAFTAR PUSTAKA}

Adang Suherman, 2000, Dasar-Dasar Penjaskes. Deparemen Pendidikan Nasional Dikdasmen Proyek Penataran Guru SLTP Setara D-III.

Ade Mardiani, dkk. 2008. Pendidikan Jasmani, Olahraga dan Kesehatan. Jakarta: Penerbit Universitas terbuka.

Agus Kristiyanto, 2010. Penelitian Tindakan Kelas dalam Pendidikan Jasmani dan Kepelatihan Olahraga. Surakarta: UNS Press

Ballesteros. 1979. Pedoman Latihan Dasar Atletik, diterjemahkan untuk PASI. Bandung. PT. Enka Parahiyangan.

Bernhard, Gunter. 1993. Atletik Prinsip Dasar Latihan Loncat Tingi, Jauh, Jangkit, dan Loncat Galah. Semarang. Dahara Prize.

Boosey, Derek. 1980. The Jumps Conditioning and Technica Training. Victoria Australia. Beatrice Publishing PTY. LTD.

Engkos Kosasih. 1985. Olahraga Teknik dan Program Latihan. Jakarta, Akademika Pressindo C.V. 
Hamalik, 2011. Kurikulum dan Pembelajaran. Bandung: Bumi Aksara.

Hans Katzenbagner/Michael Medles, 1996. Buku Pedoman Lomba Atletik, Seri 1 Nomor Lari dan Gawang, Alih Bahasa oleh PB PASI, Jakarta.

Subagiyo, 2007. Perencanaan Pembelajaran Penjaskes. UT: Jakarta.

Sudjana, 1994. Penilaian dalam Hasil Proses Belajar Mengajar. Bandung: Rosdakarya.

Tamsir Riyadi. 1985. Petunjuk Atletik. Yogyakarta. FPOK IKIP. Yogya

Wina Sanjaya, 2009. Penelitian Tindakan Kelas. Jakarta: Kencana Prenada Media Group. 